\title{
The Difference Between the Quality of Life of Young Adult Women Based on Their Working System During the Large-Scale Social Restrictions Period
}

\author{
Michelle Theodora $^{1 *}$ Agustina Agustina ${ }^{1}$ \\ ${ }^{1}$ Psychology Undergraduate Program, Universitas Tarumanagara, West Jakarta, Indonesia \\ "Corresponding author. Email: agustina@fpsi.untar.ac.id
}

\begin{abstract}
In 2020, it seems that the topic of quality of life becomes increasingly important to discuss since the existence of an infectious disease caused by COVID-19 has brought challenging changes in people's lives. One of the challenges in the pandemic situation is the changing of working system. This study aims to see whether there is a difference between the quality of life of young adults women who Work From Office (WFO) and those who Work From Home (WFH) during the Large-Scale Social Restriction period. The data was collected by distributing the WHOQOL-BREF questionnaire online. The total data processed amounted to 78 data which were then analyzed using the Kolmogorov-Smirnov normality test and the Independent Sample T-Test since the data obtained were normally distributed. Based on the results of Independent T-Test using SPSS software, the results show a significance ( $\mathrm{Sig}$ ) of $0.998>0.05$ with a mean value of 3.773 . This means that there is no significant difference between the quality of life of young adults women based on their working system during the Large-Scale Social Restriction period. In terms of the mean value per dimension, it was found that the dimension with the highest mean value was the psychological health dimension $(3,792)$, followed by the mean value of the environmental dimension $(3,766)$, psychological physical health $(3,753)$ and the lowest was the social relationship mean value $(3,645)$. Based on those results, it can be concluded that both young adults women who work from home and work from office during the Large-Scale Social Restrictions period had high quality of life values in this study. Thus, this study found that there was no significant difference between the quality of life of young adults women who work with WFO and WFH system during the LargeScale Social Restriction period.
\end{abstract}

Keywords: Quality of life, work from home, work from office

\section{INTRODUCTION}

In recent years, the concept of quality of life has become an increasingly popular topic of discussion. The increasing research on quality of life may be due to the importance of quality of life as a means of measuring health [1-3]. Health is also one of three ways to operationalize the concept of quality of life [4]. WHOQOL Group stated that there are 3 other aspects beside physical health that can also affect the quality of life. Those aspects are psychological health, social relationships, and relationships with the environment [5]. In 2020, it seems that the topic of quality of life becomes more important to discuss since the existence of an infectious disease caused by COVID-19 had brought many impacts on the quality of physical health, psychological health, social relationship and environment [6].

Previous study in China found that $52.1 \%$ of participants were horrified and worried because of the COVID-19 pandemic. However, some of them did not feel helpless due to the pandemic because some of them became more concerned with their mental health and spent more time resting and exercising after the onset of the pandemic than before [7]. Other studies about quality of life during pandemic conducted in India, Morocco, and Poland also found that there was a degradation in people's quality of life and an addition in discomfort, worry, anxiety, stress and depression during the COVID-19 pandemic [7-11]. Therefore, a study in Morocco added that apart from the benefits of prevention protocols that must be implemented to reduce the spread of COVID-19, awareness is also needed for the mental health of people who have not been infected by COVID-19. It is because the preventive protocols such as restrictions can also interfere people's work life and daily activities so that people's psychological health and quality of life might be affected as well[11].

In dealing with COVID-19, the Indonesian government has also set policies and health protocols to prevent the spread of COVID-19 just as the other countries [12]. Unfortunately, these policies and preventive protocols also 
have brought impacts on the people's quality of life in Indonesia. Based on the results of an online survey conducted by Snapcart in 8 major cities in Indonesia, it is shown that the people's social relationship and their relationships with the environment are disrupted. New policies and preventive protocols due to the COVID-19 pandemic have disrupted lifestyles, work habits and business activities. The survey results showed that $48 \%$ of the community felt that their social life was disrupted, $44 \%$ were worried about their career and work, $39 \%$ felt upset because of the cancellation of plans for holidays, events and tours; $31 \%$ felt worried because of the limited religious activities and $24 \%$ felt annoyed because they are unable to go shopping [13]. Based on that survey, we could see that the preventive protocols have disrupted the social relationship, psychological health and the relationship with environment according to the dimensions of quality of life. Even so, the government still needs to enact the health protocol to reduce the spread of COVID19 so further policy such as Large-Scale Social Restrictions (LSSR) in cities were also implemented by closing educational institutions, closing most workplaces, restricting public services, prohibiting travel, and other closure measures [14].

Based on Indonesia's LSSR policy, the government has determined that there are several business sectors that still have to operate with health protocols and $50 \%$ capacity. These sectors are health, food and beverage, energy, communications, services, communication media, banking finance including capital markets, logistics and distribution of goods, retail such as food stalls, grocery stores and other strategic industries [15]. The workers in these sectors have to work as usual (Work From Office) while other sectors have to stop operating and work from home (Work From Home) since March 15, 2020 [14]. Both systems either Work From Home (WFH) or Work From Office (WFO) during the LSSR period, each of them has their own impacts on the quality of life dimensions. One of the disadvantages of the WFO system that impacts the physical health dimension of quality of life is the WFO workers need to deal with a bigger risk and potential to be exposed to COVID-19 despite health protocols they have obeyed [16]. A study in Japan showed that among company employees, a higher fever rate was found in the group of employees who did not undergo WFH system [17]. In terms of psychological health, based on the experiences shared by some workers who did not undergo WFH during the pandemic on Bloomberg [16] and Okezone [18], most of them said they constantly felt worried about being infected by people they meet on the road. They were afraid to endanger their family at home and they were unable to breathe freely with a mask. Psychological burdens such as pressure of the responsibility mixed with the feelings of worry about COVID-19 also keep bothering their minds every time they do their job [19]. It can be seen that working from office during the Large-Scale Social Restriction period is very challenging. However, the working time limit and the direct communication that might reduce miscommunication while working are some of the WFO system advantages [20].

On the other hand, WFH system also has some advantages related to the quality of life dimensions. The secure feeling, the flexible work time and the low transportation costs are some of the advantages of the WFH systems that related to the psychological health and environtmental dimension. Yet, the workers who have undergone Work From Home (WFH) system also have challenges that related to the quality of life dimensions. Based on the results of a survey, the most prominent impact of WFH system is the mental health problems [21]. Some people may feel more comfortable with WFH system because it is safer than WFO system and it enables workers to save more time and money on transportation. However, a study involving $8,475 \mathrm{WFH}$ workers showed that 35 percent claimed that their mental health had deteriorated as a result of having to work from home system, 50.7 percent claimed it had no impact on their mental health, and 14.3 percent claimed their mental health increased. Others with prolonged WFH system were also found to have mild mental health problems, difficulty in balancing time, and difficulty in communicating with their colleagues [22]. The inadequacy in using technology can also be an obstacle for WFH workers since communication on the WFH system can only be done by online. The difference in network connection stability in each region can also become a barrier in communicating while working from home. It tends to create more miscommunication in WFH systems [20]. Moreover, the inability to set time limits for work and rest can cause burnout that eventually might lead to the unstable mental and physical health as well [20].

After further analysis, most individuals who experienced disturbances with WFO and WFH systems during the LSSR period were individuals who had entered the development stage of young adults. Young adulthood (ages 20 to 40 years) is a crucial moment for individuals because at this moment individuals begin to have their own responsibilities in completing developmental tasks such as preparing for work, building relationships and make a family [23]. Young adults who were working during the LSSR period had actually succeeded in fulfilling one of the developmental tasks that played a major role in influencing the quality of life. A study claimed that individuals who work have a better quality of life than individuals who do not work [24]. Yet, other studies found that besides the success of fulfilling developmental tasks, the quality of life of individuals is also influenced by social and environmental relationships as stated by the WHOQOL group [25].

According to Fadda and Jiron [26], the existence of gender difference between men and women might also affect a person's quality of life. This is because men and woman have different roles and control over various sources. Therefore, their needs will also be different. A survey from Snapcart [13] found that compared to $68 \%$ of male participants, $74 \%$ of female participants felt more uncomfortable working at home because they had to divide their time and focus between working and taking care of the household at the same time. The inability to 
balance work and household tasks may cause an unstable mental and physical health. Besides of that, the distraction of the home environment can also affect the productivity of WFH workers [20]. Another survey with working mothers as respondents by the Indonesian Institute of Sciences (LIPI) also found that most of them prefer WFO rather than WFH system because they feel they can be more focused and effective when working at office. In their opinion, working from home tends to make them less productive and disrupted by other responsibilities at home [27]. However, young adults women who undergone WFH and WFO both have advantages and disadvantages that might affect the four dimensions of quality of life. Therefore, this study aims to compare the quality of life of young adult women who work from office and work from home during the LSSR period.

\subsection{Related Work}

\subsubsection{Quality of life}

The World Health Organization [28] defined quality of life as an individual's perception of their position in life in the context of the culture and value system in which they live and their relationship to their goals, expectations, standards and other things that concern the individual. The first dimension of quality of life is the physical health dimension which includes the quality of sleep, energy, fatigue, dependence on drugs or medical aids, mobility, pain, discomfort, rest time, and work capacity. The second dimension is psychological health, which includes body image, appearance, negative or positive feelings, self esteem, spirituality or personal beliefs, ways of thinking, learning, memory and concentration. The third dimension is social relations, which includes personal relationships, social support, and sexual activity. The last dimension is the relationship with the environment which includes freedom, security, physical safety, transportation, opportunities for recreation, opportunities for information, skills, home environment, housing conditions, house availability, financial resources, quality of health care, social care, facilities and infrastructure that can support life [5].

\subsection{Our Contribution}

This study aims to examine the difference between the quality of life of women young adults who work with WFO and WFH system during the LSSR period. All previous studies related to quality of life during pandemic COVID-19 were conducted by foreign countries and so far no one has examined the quality of life especially during LSSR period with comparative method [7-11]. Therefore, this study aims to examine the difference between the quality of life of young adults women who work with WFO and WFH system during the LSSR period so that either young adults women work from office or work from home can pay more attention to their quality of life during the LSSR period.

\subsection{Paper Structure}

The rest of the paper is organized as follows. Section 1 introduces the phenomenon behind this research. The first section explains about the importance of quality of life, how the working systems (WFO \& WFH) during the LSSR period affect it, the disadvantages and advantages of both working systems related to the quality of life dimensions. Section 2 presents the methods how we conducted this research study to know whether there is a significant difference between the quality of life of young adults women who work with WFO systems and WFH systems during the LSSR period. Eventually, the results of this research are analyzed and disscused in section 3 . The last section which is section 4 concludes the paper and presents direction for future research.

\section{METHODS}

\subsection{Research participants and procedure}

Participants in this study were young adult women who has underwent a full Work From Office or Work From Home work system during the LSSR period from 15 March 2020 to 6 December 2020. From the data obtained, it was found that there were 78 female participants who met the partisipant criteria. The data was obtained from a questionnaire through Google Form. Then, the data was processed using Independent Sample t-test with SPSS (Statistical Product and Service Solution) software.

\subsection{Measuring instrument}

This study uses a measuring instrument in the form of a questionnaire that refers to WHOQOL-BREF to examine quality of life [28]. WHOQOL-BREF instruments consist of 26 items that measure four dimensions of quality of life. The score for each dimension is obtained from the individual's response in perceiving each item on each dimension. The score of each dimension shows the quality of life score based on the World Health Organization Quality of Life-Bref (WHOQOL-BREF) adaptation scale. Each item is measured using a Likert scale from 1 to 5 . The higher or lower the score on each dimension, the higher or lower the quality of life as well.

The reliability test of the measuring instrument in this study was processed by using SPSS version 25 . The reliability of this measuring instrument can be seen from the Cronbach Alpha value obtained. If the Cronbach Alpha value is $\geq 6.0$, it means that the item is reliable enough to measure the dimension of quality of life. 


\section{FINDING AND DISCUSSION}

In this study, 41 participants $(52.6 \%)$ were between $20-24$ years old, 24 participants $(30.8 \%)$ were between $25-29$ years old, 9 participants $(11.5 \%)$ were between $30-34$ years old, 3 participants (3.8\%) were between $35-39$ years old, and 1 participant (1.3\%) were 40 years old. Based on the data obtained in this study, there are more of young adults women who work with WFH system than with WFO system. Young adults women who work with WFH system were 58 participants with a mean value of 3,974 and young adult women who work with WFO system were 20 participants with a mean value of 3.704 .

Table 1 Item distributions

\begin{tabular}{cccc}
\hline Dimension & Items & Range & $\boldsymbol{\alpha}$ \\
\hline General & 2 & $1-5$ & .66 \\
Psychological Health & 6 & $1-5$ & .78 \\
Physical Health & 7 & $1-5$ & .79 \\
Environmental & 8 & $1-5$ & .78 \\
Social Relationship & 3 & $1-5$ & .76 \\
\hline
\end{tabular}

Table 2 Description of participant's quality of life

\begin{tabular}{cccc}
\hline & N & Mean & Std. Deviation \\
\hline WFO & 20 & 3.974 & .54 \\
WFH & 58 & 3.704 & .52
\end{tabular}

Table 3 Quality of life each dimension's score

\begin{tabular}{ccccc}
\hline Dimension & Min & Max & Mean & Std. Deviation \\
\hline Psychological Health & 2.67 & 5.00 & 3.792 & .48 \\
Environmental & 2.50 & 4.88 & 3.766 & .54 \\
Physical Health & 1.80 & 5.00 & 3.753 & .67 \\
Social Relationship & 1.67 & 5.00 & 3.645 & .81 \\
\hline
\end{tabular}

Table 2 shows the quality-of-life mean value of the young adult women who work from office was 3,974 and the quality of life for young adult women who work from home was 3,704. It can be seen that the quality of life of young adult women who work with WFH system is lower than the quality of life of young adult women who work with WFO system. After further analysis, this may be because young adult women who work with WFH system are dealing with more difficulty in maintaining focus and managing their time during WFH system than WFO system as it's found by a previous study [13].

If we see from the mean value in every dimension, it is found that the dimension with the highest mean value is the psychological health (3,792), followed by environmental dimension $(3,766)$, then physical health dimension $(3,753)$ and the lowest being social relationship $(3,645)$. These results indicate that the value of quality of life is generally high because it exceeds the hypothetical mean. These results are very different from most studies from foreign countries which show a degradation in the quality of life in general [7-11]. In this study, the dimension of relationship with the environment has the second highest mean value after the dimension of psychological health. Based on that results actually the high score in psychological health and environtmental dimension are not in line with the data obtained through 
the news and previous studies which show disruption when trying to access their surrounding during the quarantine period in the middle of the pandemic [7-11]. Nevertheless, the lowest mean value that was found in social relationship dimension is in line with the results of a study by Samlani et al. [11] which found that preventive protocols such as social restrictions can interfere with people's work and daily activities. According to WHOQOL-BREF, the social relationship dimension is related to public self-consciousness that is how individuals can communicate with other people, their personal relationships, social support, and individual sexual activity [5]. Apart from that, building social relationships is also one of the developmental tasks of young adults [29]. Therefore, it is possible that both of the working systems have affected the communication and social relationship of young adult women in this study since the social relationship dimension has the lowest mean value. However, even though this social relationship dimension has the lowest mean value after all, the quality of social relationship in this study is still considered high because it exceeded the hypothetical mean of this study. Yet, it also shows that this dimension is the dimension that is most affected by changes in the work system during the LSSR period.

After further review, the high level of psychological health in young adult women who are working from home or from office in this study is in line with the results of a survey in Tokyo. The participants in their study stated that $50.7 \%$ of them feel that their mental health was not affected and $14.3 \%$ said their mental health had improved [17]. In addition, the high quality of life score in this study is similar to the results of Zhang and Ma's study [7] which showed that some of the participants actually felt that their quality of life had improved because they paid more attention to their mental health and had more time to rest and exercise after the onset of the pandemic than before.

This might also be one of the reasons that can explains how the mean value of the psychological health and physical health dimensions were still high even though there are so many changes in work systems during the LSSR period.

Table 4 Independent sample t-test results

\begin{tabular}{llllll}
\hline & $\mathrm{N}$ & Min & Max & Mean & Sig. \\
\hline QOL & 78 & 2.51 & 4.94 & 3.7736 & .998 \\
\hline
\end{tabular}

If we see from the results of the Independent Sample t-test between the two groups of work systems, the results show a significance value (Sig) of $0.998>0.05$ with a mean value of 3.773 . This shows that there is no significant difference between the quality of life of young adult women who work with WFO and WFH systems during the LSSR period. This may be because both WFO [16-20,27] and WFH [20-22] systems have their own advantages and disadvantages so that no significant difference was found [30].
Nevertheless, there are limitations in this study that may affect the results such as the imbalance amount of WFH and WFO participants. Apart from the limited time for collecting participant data, most of people did not work with one of the working system only from the start to the end of the LSSR period. Therefore, workers who did not completely work with only one of the working system could not participate in this study. Another limitation is this study has not been specific enough in determining sample characteristics. Items on the measuring instrument are also need to be associated more with the phenomena in this study. Therefore, further research is expected to overcome the limitations of this study by collecting a larger sample size so that the results can be generalized to the population in Indonesia as well. In addition, it is suggested for further research to use other psychological variables such as quality of work life (QWL) that is more relatable in identifying the difference between young adults who work with WFO and WFH system.

\section{CONCLUSION}

This study aims to identify whether there is a difference between the quality of life of young adult women who work with WFO and WFH system during the LSSR period. Based on the results of the analysis and data processing using the Independent Sample t-Test, it was found that there was no significant difference between the quality of life of young adults women who work with WFO system and WFH system during the LSSR period. The high mean value of quality of life also indicates that the changing of working system during the LSSR period did not have a significant impact on the quality of life of the young adults in this study.

\section{ACKNOWLEDGMENT}

Researcher would like to thank the university for the opportunity, every participant who was willing to participate and everyone who has contributed to this research.

\section{REFERENCES}

[1] A. Malkoç, Quality of life and subjective well-being in undergraduate students, Procedia Soc Behav Sci, 2011, vol. 15, pp. 2843-2847. DOI: 10.1016/j.sbspro.2011.04. 200

[2] F. K. Saravi, A. Navidian, E. E. Tabas, T.S. Shad, Prediction of the quality of life in the adolescents with diabetes based on self-efficacy, Med Surg Nurs J, 5(3) (2016) 43-49.

[3] W. H. Utian, J. W. Janata, S. A. Kingsberg, M. Schluchter, J. C. Hamilton, The Utian Quality of Life 
(UQOL) Scale, Menopause, 25(11) (2018) 1224-1231. DOI: $10.1097 /$ gme.000000000000122 3.

[4] M. W. M. Post, L. P. Witte, A. J. P. Schrijvers, Quality of life \& the ICIDH: Toward \& integrated conceptual model for rehabilitation outcomes research. Clinical rehabilitation, 1999, vol. 13, pp. 5-15. DOI: 10. 1191/026921599701532072

[5] M. J. Power, Quality of Life. In Lopez, S. J., \& Snyder, C. R. (Eds). Positive psychological assessment: A handbook of models and measure, American Psychological Association, 2003, pp. 427-441. DOI: 10. 1037/10612-027

[6] Antisipasi dampak COVID-19, ancaman penurunan kualitas kesehatan massal, Muda News, May. 2020. [Online]. Available: https://mudanews.com/lingkungan kesehatan/2020/05/12/antisipasi-dampak-covid-19ancaman-penurunankualitas-kesehatan-massal/

[7] Y. Zhang, Z. F. Ma, Impact of the COVID-19 pandemic on mental health and quality of life among local residents in Liaoning province, China: A cross-sectional study. International Journal of Environmental Research and Public Health, 17(7) (2020) 2381. DOI: https://doi. org/10.3390/ijerph17072

[8] J. Chwaszcz, A. Palacz-Chrisidis, M. Wiechetek, R. P. Bartczuk, I. Niewiadomska, P. Wośko, P. Sławska. Quality of life and its factors in the COVID-19 pandemic situation. Results of Stage 1 studies during the pandemic growth period, 2020. DOI: https://doi.org/10.31234/osf.io/ ryv8g

[9] R. C. Patra, B. Kanungo, P. Bawa, Mental health, sleep quality and quality of life in individuals with and without multiple health conditions during home quarantine in India due to the COVID-19 pandemic: a cross-sectional study. [version 1; peer review: awaiting peer review] 2020, F1000 Research, vol. 9, pp. 718. DOI: https://doi.org /10.12688/f1000research.24321.1

[10] W. Ping, J. Zheng, X. Niu, C. Guo, J. Zhang, H. Yang, Y. Shi, Evaluation of health-related quality of life using EQ-5D in China during the COVID-19 pandemic. PLOS ONE, 15(6) (2020) 0234850. DOI: 10.1371/journal.pone. 0234850

[11] Z. Samlani, Y. Lemfadli, A. A. Errami, S. Oubaha, K. Krati, The impact of the COVID-19 pandemic on quality of life and well-being in morocco, Preprints, 2020. DOI: 10.20944/preprints202006.0287.v1.

[12] Mengapa kasus COVID-19 terus meningkat dan kasus kematian menurun? Kompas, Sept. 2020. [Online]. Available: https://www.kompas.com/tren/read/2020/09/08/ 073500365/mengapa-kasus-covid-19-terus-meningkat-dan -kasus-kematian-menurun-?page $=$ all.
[13] COVID-19 impact on Indonesian shopper habits, Snapcart, Apr. 2020. [Online]. Available: https://snapcart. global/2020/04/16/

[14] Ini arahan lengkap Jokowi demi mencegah meluasnya corona di Indonesia, Kompas.com, Mar. 2020. [Online]. Available: https://nasional.kompas.com/read/2020/03/15/ 15432101/ini-arahan-lengkap-jokowi-demi-mencegahmeluasnya-corona-di-indonesia?page=all

[15] Apa itu WFO, Warta Ekonomi, Dec. 2020. [Online]. Available: https://www.wartaekonomi.co.id/read318346/ apa-itu-wfo/0

[16] The ones who can't work from home, Bloomberg, Apr. 2020. [Online]. Available: https://www.bloomberg. com/features/2020-essential-workers-coronavirus/

[17] T. Kawashima, S. Nomura, Y. Tanoue, D. Yoneoka, A. Eguchi, S. Shi, H. Miyata, The relationship between fever rate and telework implementation as a social distancing measure against the COVID-19 pandemic in Japan, Public Health, 2020. DOI: https://doi.org/10.1016/ j.puhe.2020.05.018.

[18] Cerita karyawan yang tetap bekerja di tengah pandemi COVID-19, Okezone, Apr. 2020. [Online]. Available: https://nasional.okezone.com/read/2020/04/01/ 337/2192279/cerita-karyawan-yang-tetap-bekerja-ditengah-pandemi-covid-19.

[19] Mengusir stres bekerja di luar rumah saat corona mewabah, Kompas, Apr. 2020. [Online]. Available: https: //money.kompas.com/read/2020/04/04/070900726/mengus ir-stres-bekerja-di-luar-rumah-saat-corona-mewabah?page $=$ all.

[20] Work From Office (WFO) vs Work From Home (WFH), pilih mana? Insight Talenta, Jun. 2020. [Online]. Available: https://www.talenta.co/blog/insight-talenta/ work-from-office-vs-work-from-home-pilih-mana/

[21] Waspada dampak WFH pada kesehatan mental, Republika, Aug. 2020. [Online]. Available: https:// republika.co.id/berita/qf3hjy335/waspada-dampak-wfhpada-kesehatan-mental

[22] Survey: $35 \%$ say working from home has harmed mental health, Fox Business Association, Apr. 2020. [Online]. Available: https://www.foxbusiness.com/ healthcare/working-from-home-has-harmed-mental-health -survey

[23] D.E. Papalia, R.D. Feldmand, Menyelami perkembangan manusia (Ed.12), Salemba Humanika, 2014.

[24] B. Hultman, S. Hemlin, J.O. Hornquist, Quality of life among unemployed and employed people in northern 
Sweden, Are there any differences? Work, 26(1) (2006) 47-56.

[25] V. Pukeliene, V. Starkauskiene, Quality of life: Factors determining its measurement complexity, Journal of Inzinerine Ekonomika Engineering Economics, 22 (2) (2011) 147-156. DOI: http://dx.doi.org/10.5755/j01.ee.22. 2.311

[26] G. Fadda, P. Jiron, Quality of life and gender: a Methodology for urban research, Environment and Urbanization, 1999. DOI: https://doi.org/10.1177/ 095624789901100220

[27] Dilema Ibu Bekerja WFH atau WFO? Kumparan, Sept. 2020. [Online]. Available: https://kumparan.com/ winarnikandar/dilema-ibu-bekerja-wfh-atau-wfo-

1uFq41WqPN3/full

[28] WHO Quality of Life Assessment Group, What quality of life? / The WHOQOL Group, World Health Forum, 17(4) (1996) 354-356.

[29] Havighurst, J, Robert. Human development and education. Surabaya: Sinar Wijaya, 1985.

[30] Covid-19 belum juga berakhir, lebih baik WFH atau WFO? Indonesia Terhubung, Sept. 2020. [Online]. Available: https://indonesiaterhubung.id/artikel/526/covid19-belum-juga-berakhir-lebih-baik-wfh-atau-wfo 